\title{
Economic Analysis of Cashewnut Processing Units in Srikakulam District of Andhra Pradesh, India
}

\author{
Sirela Bharat ${ }^{*}$, A.K. Sarawgi and Yogeshwari Sahu \\ Department of Agricultural Economics and Farm Management, College of Agriculture, \\ JNKVV, Jabalpur, India \\ *Corresponding author
}

\section{A B S T R A C T}

A study was conducted to examine the present status of cashewnut production in Srikakulam District of Andhra Pradesh and to work out the cost and returns of selected

Keywords

Relative change, Net returns, Break even point, $\mathrm{BCR}$

Article Info

Accepted:

04 October 2018

Available Online:

10 November 2018 cashewnut processing units. A sample of 10 processing units comprising of 5 processing units from two groups namely Group I and Group II processing units were selected based on per day processing capacity. The study concluded that the relative change for area, production and productivity of cashewnut was positive in the district. It was also observed that per quintal cost of processing was higher in case of Group-I (Rs.17409.77) processing units compared to Group-II (Rs.17220.87). The major costs were raw material cost (Rs.12109) and labour wages (Rs.2507.55) at the overall level. Net returns realized per quintal processing of cashewnut were higher in Group-II (4298.63) processing units than Group-I (3410.73). The overall break-even point was worked out to be 181.02 quintal, which was found to be 121.93 and 228.40 quintal in Group-I and Group-II processing units respectively. BCR was worked out to 1.18 and 1.24 for Group-I and Group-II processing units respectively. At overall level NPW was worked out to be $658.21 \mathrm{Rs}$. lakh at 12 per cent rate and IRR was 35.65.

\section{Introduction}

Horticulture sector is gaining lot of importance in India due to its contribution to Indian economy in terms of income and employment generation to millions of people in rural areas. Among horticulture crops, plantation crops (cashewnut) are high valued commercial crops because of their vital role in the Indian economy. These crops contribute to export earnings, provide employment to many millions of people and conserve the soil and ecosystem.
Anacardium occidentale L. (Anacardiaceae, $2 \mathrm{n}=42$ ), commonly known as cashewnut is a native of Eastern Brazil, was introduced in India by the Portuguese nearly five centuries ago i.e., during 16th century. The first introduction of cashew in India was made in Goa from where it spread to other parts of the country. The crop is mainly grown on the waste lands in high rainfall areas for its nuts and to check soil erosion. Hence it is considered as 'Gold mine' of waste land as it requires low inputs for production. In the early years it was only a crop for afforestration and soil conservation. It has now emerged as one 
of the most important dollar earning plantation crops in India.

The raw cashewnut is the main commercial product of the cashew tree. Raw nuts are either exported or processed prior to export. Processing of raw nut yields kernel, shell, rejection and husk. Cashew kernels are consumed in the form of snacks and used in confectionery. Cashewnut is one of the most important plantation crop earning huge foreign exchange through its kernels and cashew nut shell liquid(CNSL). The share of agricultural products in the total export earnings of the country during 2016-17 (April 2016 to March 2017 ) is 6.65 per cent and cashew kernels ranked 7 th among them contributing 4.30 per cent of the agri products exports. This accounts to 0.29 per cent of the total foreign exchange earnings of the country through exports. The total export of cashew kernels from India during 2016-17 was 82,302 M.T. valued at Rs. 5168.78 Cr. USA, Netherland, U.K., Japan, UAE, France, Canada, Saudi Arabia, Singapore, Italy, German Fed. Republic, Austria, Israel and Spain are the major International buyers of Indian Cashew.

The production of raw cashewnuts in India during 2016-2017 was 7,79,335 M.T. Cashewnut is presently grown in an area of 1041 thousand hectares with an annual production of $7,79,335$ M.T. in the country. The main cashew growing and processing states are kerela, Karnataka, Tamilnadu, Andhra Pradesh, Maharashtra, Goa and Orissa. Andhra Pradesh is the largest producer of cashewnut in the country after Maharashtra, with an area of 185.57 thousand hectares and production of 111.39 ('000 MT) in the country (2016-17). In the context of growing demand for cashew kernels in domestic market as well as foreign countries, an attempt has been made in this investigation to review economic analysis of cashew processing units in Srikakaulam District of Andhra Pradesh, as the district has considerable area under cashewnut (24087 ha) 2016-17. The growth of the Agro Industries is utmost important in case of the bifurcated Andhra Pradesh state as it generates employment and also provides good source of revenue to the government which is facing deficit budget. In this context, this study which encompasses the cost and returns of the processing units in it would be immense help to the processors and the government for policy formulation on cashewnut. Therefore the study was carried out on "Economic Analysis of Cashewnut processing units in Srikakulam District of Andhra Pradesh" with the following specific objectives:

To examine the present status of cashewnut production in Srikakulam District of Andhra Pradesh.

To workout the cost and returns of selected cashewnut processing units under different capacity in the study area.

The findings under the study will be helpful to different agencies involved in processing of cashewnuts for planning of their future policies. It will also provide necessary feedback to cashew units, policy makers in formulating the plans and policies for the development of cashewnut processing. The study also will be very useful for new entrepreneurs to decide products to be processed after studying its benefits and will also be helpful to other investigators and research workers to know the existing position of cashewnut processing in Srikakulam District of Andhra Pradesh state.

\section{Materials and Methods}

The present study was carried out in Srikakulam district of Andhra Pradesh. Srikakulam district was the main processing center for cashewnut in Andhra Pradesh state. Further, it has considerable area of cashewnut 
orchards in an area of 24087 ha (2016-17). In addition, there were more than 292 processing units. District having 38 mandals, a list of mandals having cashewnut processing units were prepared and among them two mandalspalasa and mandasa having highest concentration of cashewnut processing units were selected. After selection of mandals, a list of cashewnut processing units were prepared and further divided into two groups based on the total quantity processed per day i.e., Group I (upto $1000 \mathrm{Kg}$ ) and Group II (above 1000Kg). From each Group 5 processing units were selected randomly for detail investigation. Thus total 10 cashewnut processing units were selected. The data on processing aspects of cashewnut were collected from the owners of the processing units to fulfill the stated objectives.

The Primary data pertains to Agriculture year 2016-17. The Secondary data from the year 2006-07 to 2015-16 were collected from various sources like National horticulture Board, Directorate of cashew and Cocoa Development, District Industry Centre, Srikakulm and from other sources.

\section{Analysis of data}

In order to fulfill the objectives of the study, the collected data was analyzed by using appropriate techniques and tools like absolute change and relative change, cost elements (fixed, variable and total costs), ratio analysis, break even analysis, and investment analysis.

\section{Results and Discussion}

\section{Absolute and Relative change}

The changes in the Area, Production, Productivity of cashewnut under selected area have been analyzed in the form of Absolute change and Relative change in current year over the base year during the study period and these have been presented in the Table 1 and 2
It revealed from the Table 1 that relative change for the area, production and productivity of cashewnut was observed positive in mandasamandal and Srikakulam district. In case of palasamandal the area of cashewnut was observed to have a negative change while the production and productivity of cashewnut was observed to have positive change. Thus it could be concluded that positive change in production and productivity of cashewnut in the study area which shows a good sign for increasing the productivity level of plantation crop in the study area.

It was observed from the table that relative change for area, production of cashewnut was observed to have positive change while the productivity was decreased from base year to current year by $(-38.98 \%)$. Thus it can be concluded that though the area was increased the productivity was not upto the mark, this may be due to the fact that the increase in area and production was not at a same pace i.e., the change in area is five times more than the production.

\section{Cost and return analysis}

\section{Classification of cashewnut processing units}

From the Table 3 it is evident that the processing units are classified as Group-I having processing capacity upto $1000 \mathrm{Kg}$ /day and Group-II having processing capacity more than $1000 \mathrm{Kg} /$ day. From each group five processing unit were considered. Thus the total 10 processing units were considered for the detailed investigation.

\section{Processing capacity of selected cashewnut Processing units}

On an Average the processing capacity and number of working days of the selected processing units under two groups are given in the Table 4. 
It is evident from the Table 4 that the overall working days of the cashewnut processing units was 266 which covers about 72 percent working days in the year. The number of working days in case of Group-I 255 and in the Group-II it was 276 working days. The Average quantity processed per day was 653.2 $\mathrm{kg}$ and $1546 \mathrm{~kg}$ under Group-I \& II respectively. The difference in processed quantity in selected group may be due to the installed capacity of the processing units. Thus the Annual quantity processed in case of Group-I was $1,66,565 \mathrm{Kg}$ and in Group-II it was 4,26,685 $\mathrm{Kg}$. On an average the level the annual quantity processed was $2,91,943.8 \mathrm{Kg}$.

\section{Per quintal cost of cashewnut processing}

It was observed from the Table 5, that the per quintal cost of processing for Group-I was Rs.17409.77 which was higher than Group-II which was Rs.17220.87. At overall level per quintal cost of processing was Rs. 17,315.22.

A part from the raw material cost, the major cost was on wages which was Rs.2507.55. The other important items were interest on working capital Rs.1550.82, taxes Rs.738.69, depreciation Rs 90.23, salaries of permanent labour Rs.83.03, Interest on Fixed capital Rs. 62.90, power Rs. 62.76 .

Thus it could be concluded that the per quintal cost of processing exhibited inverse relationship with the scale of production. Also it was observed that the fixed cost was marginally higher in Group-I (Rs 269.4 per quintal) while in Group-II it was (Rs 243.1 per quintal), because of higher interest on fixed capital, depreciation, salaries of permanent labour. Hence, there is need to utilize fully the installed capacity of processing by the Group-I units to reduce the burden of fixed cost.

Table.1 Absolute and relative change in area, production and productivity of cashewnut in selected Mandals and Srikakulam District (2012-13 to 2016-17)

\begin{tabular}{|c|c|c|c|c|c|c|}
\hline \multirow[t]{2}{*}{ Particulars } & \multicolumn{3}{|c|}{ Absolute change (AC) } & \multicolumn{3}{|c|}{ Relative change (\%) (RC) } \\
\hline & $\begin{array}{l}\text { Area } \\
\text { (ha) }\end{array}$ & $\begin{array}{l}\text { Production } \\
\text { (MTs) }\end{array}$ & $\begin{array}{l}\text { Productivity } \\
\text { (MTs/ha) }\end{array}$ & $\begin{array}{l}\text { Area } \\
\text { (ha) }\end{array}$ & $\begin{array}{l}\text { Production } \\
\text { (MTs) }\end{array}$ & $\begin{array}{l}\text { Productivity } \\
\text { (MTs/ha) }\end{array}$ \\
\hline \multicolumn{7}{|c|}{ 1) Selctedmandals } \\
\hline a) Palasa & -92 & 11.96 & 0.04 & -5.8 & 1.5 & 7.84 \\
\hline b) Mandasa & 221 & 163.92 & 0.015 & 6.92 & 10.06 & 2.94 \\
\hline \multicolumn{7}{|l|}{ 2) District } \\
\hline Srikakulam & 71 & 2191.8 & 0.09 & 0.29 & 17.9 & 17.64 \\
\hline
\end{tabular}

Table.2 Absolute and relative change in area, production and productivity of cashewnut in Andhra Pradesh (2005-06 to 2016-17)

\begin{tabular}{|l|c|c|}
\hline Particulars & Absolute change & Relative change (\%) \\
\hline Area ('000ha) & 14.87 & 8.17 \\
\hline Production ('000MT) & 2.96 & 2.97 \\
\hline Productivity (Kg/ha) & -34.7 & -38.98 \\
\hline
\end{tabular}


Table.3 Classification of cashewnut processing units

\begin{tabular}{|l|l|l|}
\hline Processing units & $\begin{array}{l}\text { Installed capacity } \\
\text { (Kg/Day) }\end{array}$ & No. of units selected \\
\hline Group I & $<1000$ & 5 \\
\hline Group II & $>1000$ & 5 \\
\hline
\end{tabular}

Table.4 Processing capacity of selected cashewnut processing units

\begin{tabular}{|c|c|c|c|c|}
\hline \multirow[t]{2}{*}{ S. No } & \multirow[t]{2}{*}{ Particulars } & \multicolumn{2}{|c|}{ Processing units } & \multirow[t]{2}{*}{ overall } \\
\hline & & Group I & Group II & \\
\hline 1 & No. of Working Days (per year) & 255 & 276 & 265.5 \\
\hline 2 & $\begin{array}{l}\text { Average Quantity Processed Per } \\
\text { day }(\mathrm{Kg})\end{array}$ & 653.2 & 1546 & 1099.6 \\
\hline 3 & $\begin{array}{l}\text { Annual Quantity Processed }(\mathrm{Kg}) \\
\text { (as per total working days) }\end{array}$ & 166565 & 426685 & 291943.8 \\
\hline
\end{tabular}

Table.5 Per quintal cost of cashewnut processing

Units: Rs

\begin{tabular}{|c|c|c|c|c|}
\hline \multirow[t]{2}{*}{ S. No } & \multirow[t]{2}{*}{ Items of cost } & \multicolumn{3}{|c|}{ Processing unit } \\
\hline & & Group-I & Group-II & Overall \\
\hline 1 & Raw material & 12120 & 12098 & 12109 \\
\hline 2 & Fuel charges & 70.35 & 17.54 & 43.94 \\
\hline 3 & Power & 79.96 & 45.56 & 62.76 \\
\hline 4 & Wages & 2526.04 & 2489.06 & 2507.55 \\
\hline 5 & Packaging materials & 4.21 & 10.82 & 7.52 \\
\hline$\overline{6}$ & $\begin{array}{l}\text { Transportation \& } \\
\text { Handling }\end{array}$ & 42.15 & 35.35 & 38.75 \\
\hline 7 & Taxes on raw material & 739.41 & 737.97 & 738.69 \\
\hline 8 & $\begin{array}{l}\text { Interest on Working } \\
\text { capital }(\mathbf{1 0 \%})\end{array}$ & 1558.21 & 1543.43 & 1550.82 \\
\hline & Sub total & 17140.36 & 16977.75 & 17059.06 \\
\hline 9 & Depreciation & 93.75 & 86.70 & 90.23 \\
\hline 10 & Rental value & 24.25 & 15.93 & 20.09 \\
\hline 11 & $\begin{array}{l}\text { Salaries of permanent } \\
\text { labour }\end{array}$ & 84.05 & 82.02 & 83.03 \\
\hline 12 & $\begin{array}{l}\text { Interest on Fixed } \\
\text { capital }(8 \%)\end{array}$ & 67.35 & 58.45 & 62.90 \\
\hline & Total & 17409.77 & 17220.87 & 17315.22 \\
\hline
\end{tabular}


Table.6 Recovery of main product and byproduct from one quintal of rawnuts

\begin{tabular}{|c|c|c|c|}
\hline \multirow[t]{2}{*}{ Item } & \multicolumn{2}{|c|}{ Processing unit } & \multirow[t]{2}{*}{ Overall } \\
\hline & Group-I & Group-II & \\
\hline $\begin{array}{l}\text { Kernel } \\
\text { Recovery* (Kg) }\end{array}$ & 28.875 & 29 & 28.93 \\
\hline Price $(\mathrm{Rs} / \mathrm{Kg})$ & 707 & 728 & 717.5 \\
\hline Value (Rs/Qt) & 20414.625 & 21112 & 20757.27 \\
\hline $\begin{array}{l}\text { Shell } \\
\text { Recovery* (Kg) }\end{array}$ & 66.25 & 66.25 & 66.25 \\
\hline Price $(\mathrm{Rs} / \mathrm{Kg})$ & 5 & 5 & 5 \\
\hline Value (Rs/Qt) & 331.25 & 331.25 & 331.25 \\
\hline $\begin{array}{l}\text { Husk } \\
\text { Recovery* (Kg) }\end{array}$ & 2.5 & 2.5 & 2.5 \\
\hline Price $(\mathrm{Rs} / \mathrm{Kg})$ & 15.6 & 17 & 16.3 \\
\hline Value(Rs/Qt) & 39 & 42.5 & 40.75 \\
\hline $\begin{array}{l}\text { Rejection } \\
\text { Recovery*(Kg) }\end{array}$ & 2.375 & 2.25 & 2.31 \\
\hline Price $(\mathrm{Rs} / \mathrm{Kg})$ & 15 & 15 & 15 \\
\hline Value(Rs/Qt) & 35.625 & 33.75 & 34.6 \\
\hline Gross returns(Rs/Qt) & 20820.5 & 21519.5 & 21163.87 \\
\hline
\end{tabular}

Table.7 Cost and return from processing of cashewnuts

\begin{tabular}{|c|c|c|c|c|}
\hline \multirow[t]{2}{*}{ S. No } & \multirow[t]{2}{*}{ Particulars } & \multicolumn{3}{|c|}{ Processing unit } \\
\hline & & Group-I & Group-II & overall \\
\hline 1 & Total cost & 17409.77 & 17220.87 & 17315.22 \\
\hline 2 & Total Return & 20820.5 & 21519.5 & 21163.87 \\
\hline 3 & Net Return & 3410.73 & 4298.63 & 3848.65 \\
\hline
\end{tabular}

Table.8 Economic viability of cashewnut processing units

\begin{tabular}{|l|}
\multicolumn{1}{|c|}{ Particulars } \\
\hline Annual Quantity Processed (Kg) \\
\hline $\begin{array}{l}\text { Kernel recovery per qt raw nut } \\
\text { processed (Kg) }\end{array}$ \\
\hline Gross Returns (Rs.lk) \\
\hline Fixed coxt \\
\hline Per qt variable cost \\
\hline $\begin{array}{l}\text { Price received per qt processed } \\
\text { raw nut (Rs) }\end{array}$ \\
\hline Break even volume (qt) \\
\hline NPV Rs @12 percent \\
\hline BCR \\
\hline IRR \\
\hline
\end{tabular}

\begin{tabular}{|r|r|r|}
\hline \multicolumn{3}{|c|}{ Processing unit } \\
\hline Group-I & Group-II & overall \\
\hline 166565 & 426685 & 291943.8 \\
\hline 28.87 & 29 & 28.93 \\
\hline & & 632.50 \\
\hline 446.79 & 918.20 & $7,43,056$ \\
\hline 17140.754 & $10,37,358$ & 17059.06 \\
\hline 20820.49 & 21519.5 & 21163.87 \\
\hline & & 181.02 \\
\hline 121.93 & 228.40 & $658,21,755$ \\
\hline $1.34,288$ & $10,08,09,225$ & 1.22 \\
\hline 25.78 & 1.24 & 35.65 \\
\hline
\end{tabular}


Recovery of main product and byproduct from one quintal of rawnuts

A perusal of Table 6 revealed that returns were maximum in case of Group-II (Rs. 21519.5/quintal) followed by Group-I (Rs. 20820.5). Price obtained for main product and by product varied across the groups of processing units. The overall price obtained was Rs 717.5 per $\mathrm{Kg}$, Rs 5 per kg, Rs. 16.3 per $\mathrm{kg}$, Rs 15 per $\mathrm{Kg}$ for cashewnut, shells, husk and rejection respectively.

Net returns from the processing of cashewnut

The net return generated per quintal of cashewnut processing under different groups of processing units is presented in Table 7.

It revealed from the Table 7 that Group-II had earned more profit than Group-I with a difference of Rs.888 per quintal. The net return realised in Group-II was Rs. 4298.63/quintal while, it was less in case of Group-I (Rs. 3410.73/quintal). The overall net return was Rs. 3848.65/quintal.

The total returns showed increasing trend with the size of processing units. The share of the kernels was highest in total returns. Higher recovery percentage coupled with higher price enabled Group-II processing units to obtain more returns. The higher return among Group-II processing units was mainly due to the economies of large scale production. The quantity procured and processed by the Group-II processing units was nearly two and half times higher than that of the Group-I processing units.

Thus, it can be concluded that the Group-II processing units earned more profits through large scale production of kernels and other by-products. In order to increase the net returns in case of Group-I processing units, their efficiency needs to be improved by increasing their capacity utilization by increasing their working capital base. It is also necessary to provide facilities such as quality raw nuts, necessary infrastructure, and efficient/skilled labour and regular power supply.

\section{Economic viability of cashewnut processing units}

The economic viability of the cashewnut processing units was studied by using different ratios viz. break-even point, net present value, benefit cost ratio, internal rate of returns.

In general, BEP is the point at which gains equal losses. At break-even point, the revenues of the business are equal its total costs and its contribution margin equals its total fixed costs. NPW is the difference between the present value of cash inflows and the present value of cash outflows.

NPV is used in capital budgeting to analyze the profitability of an investment or project. BCR is a ratio attempting to identify the relationship between the costs and benefits of a proposed project. IRR is the discount rate often used in capital budgeting that makes the net present value of all cash flows from a particular project equal to zero.

The break- even point, NPV, IRR, BCR of cashew-nut processing units are estimated and presented in Table 8.

The overall level break-even point in cashewnut processing units was 181.02 quintal, which was 121.93 quintal in Group-I processing units, 228.40 quintals in Group-II processing units and overall level NPV was worked out to be $658.21 \mathrm{Rs}$. Lakh at 12 per cent rate, whereas the BCR was accounted to 1.22 and IRR was worked out to 36.65 . 


\section{Suggestions}

The study area is very potential for cashewnut plantation but as per the findings of trend and growth rate, it indicates decreasing the area of cashewnut. So concerned department or agencies must be taken seriously to identify the reasons or constraints, than it will be helpful to increase the area of cashewnut by the policy makers. In the study area, the existing processing units are more labour intensive. It is suggested to install the improved machinery in the processing units there by kernel recovery percentage also will be increased. Existence of a large number of cashew processing units in the study region has created an un-healthy competition among the processing units with respect to procurement of limited quantity of raw nuts which in turn resulted in the under-utilization of the capacity. There is a scope for establishment of processing units in other regions of the district, on cooperative basis.

\section{References}

Banarji S and Shrivastava SL. (2014). Economic Analysis of Cashewnut
Processing in India. Economic Affairs. 59(3): 429-437.

Mamatha TG, Gummagolmath KC and Shripad PV. (2002). Trends Analysis on Production and Exports of Cashew in India. The Cashew 16(1):13-17.

Salam, M.A., Satheesh Babu and Balasubramanian, P.P. (1992). Trends in cashew production in Kerala - An Analysis. The Cashew, 5(3):3-7.

Talathi JM, Thorat VA, Patil HK. (2007). The economics of selected cashew processing units in Ratnagiri District. Paper presented in National Seminar on Research, Development and Marketing of Cashew, 20th - 21th Nov

Wadkar SS, Ghore ST, Mahindre Prakash, Malave DB, Dalavi MB. (2016)b. Cashew Processing in south Konkan region - An economic analysis. Maharashtra Journal of Agril. Economics 19(1):227.

Yadav S. (2010). Economics of Cashew in India. National Bank of Agriculture and Rural Development, Department of Economic analysis and Research, Occasional paper-50.

\section{How to cite this article:}

Sirela Bharat, A.K. Sarawgi and Yogeshwari Sahu. 2018. Economic Analysis of Cashewnut Processing Units in Srikakulam District of Andhra Pradesh, India. Int.J.Curr.Microbiol.App.Sci. 7(11): 195-202. doi: https://doi.org/10.20546/ijcmas.2018.711.023 